\section{Re: Den gamle mannen og frakken}

«Der jeg før så en senior, ser jeg nå en mentor,» skriver Lasse Pihlstrøm i Tidsskriftet nr. 2/2015 (1). Hans betraktninger om den gamle mannen og frakken bringer hans tanker tilbake til Homers epos Odyseen der Odyssev møter den «grånende mentor». Pihlstrøm skriver videre: «Vår kultur dyrker først og fremst ungdommen. I deler av arbeidslivet er det fleksibilitet, mobilitet, tempo og dynamikk som nå verdsettes høyest, fremfor klassiske verdier som erfaring, klokskap, lojalitet og stabilitet. Henger man ikke med i svingene, blir man fort sett på som gammel og avdanket.» Så føyer han til: «Svært sjelden har jeg hørt en kollega kalle en annen lege avdanket.»

Dette innlegget av Pihlstrøm er imponerende godt av en noe yngre lege. Han viser at kunnskaper ikke behøver å være til hinder for at man også kan ha forstand. Jeg føler imidlertid behov for å informere forfatteren om følgende: Norge, som det eneste landet i verden, fratar legene autorisasjon ved fylte 75 år - uten noen begrunnelse. Dette må bety at på dette tidspunkt i legekarrieren anses vi av norske helsemyndigheter for å være avdankete som leger. Annerledes er det vel ikke mulig og tolke dette. Det at avautoriseringen ikke begrunnes, betyr vel at det anses som unødvendig.

\section{Einar Skatteboe \\ einskat@online.no}

Einar Skatteboe (f. 1936) er spesialist i samfunnsmedisin og pensjonert lege.

Ingen oppgitte interessekonflikter

\section{Litteratur}

1. Pihlstrøm L. Den gamle mannen og frakken. Tidsskr Nor Legeforen 2015: 135: 162.

\section{Re: Cannabis som medisin}

Jørgen Bramness' kronikk om cannabis i Tidsskriftet nr. 3/2015 var interessant lesning (1), men behovet for at vi også her i Norge må prioritere mer forskning for at vi med større sikkerhet og kompetanse skal kunne ta i bruk cannabis som medisin, er oversett. Samtidig fremstår det for meg som om kulturelt betingede antakelser kanskje overskygger objektiviteten i enkelte påstander.

Det er lite som tilsier at cannabis i seg selv gir nevneverdig nedsatt helse eller økt risiko for sykdom hos brukeren. Det dokumenterte skadeomfanget er langt mindre enn de forbundet med lovlige rusmidler og medisiner med utstrakt bruk i samfunnet vårt, som f.eks alkohol, opiater eller benzodiazepiner (2). Moderne alternativer til røyking av cannabis, som spiselig ekstrakt og fordamping, reduserer også skadepotensialet. En studie har vist at kombinasjonen av opiater og fordampet cannabis kan redusere smerte hos kroniske smertepasienter (3). Kombinasjonen kan gi pasienten redusert opiatbehov og dermed færre bivirkninger.

Jeg mener det kulturelle stigmaet rundt denne planten har fătt mange lekmenn, helsepersonell og til og med forskere til å overføre aspekter av sykdomsbildet til individer som medisinerer/ruser seg på cannabis over på virkestoffet, uten noe medisinsk/farmakologisk grunnlag (4). Det er på tide at diskusjonen angående både medisinsk bruk og rekreasjonsbruk av cannabis kommer seg forbi fordommer som fortsatt preger den offentlige debatten, når fordommene i stadig økende forstand kan anses å være motbevist av den kumulative kunnskaps- og erfaringsbaserte litteraturen som er tilgjengelig i dag (5).

Jeg synes mye tyder på at stigmatisering, internerte misoppfatninger om psykofarmakologien og frykt for straff ved bruk av illegale rusmidler har en større innvirkning på individets psykiske helse enn rusmiddelet i seg selv. Et praktisk eksempel på skadevirkningen av forbudspolitikken i Norge er den medisinske bruken av morfin og ritalin, kontra ulovlig heroin og amfetamin, hvor skadevirkningene i større grad er til stede når produktet ikke er kvalitetssikret og titrering skjer ved risikabelt brukerutstyr og produkt med ukjent potens. Ved daglig bruk er den økonomiske belastningen i seg selv enorm.

Angående legaliteten til rusmidler, fra cannabis til opiater, er det fortvilende å se ordet «frislipp» i kontekst av legalisering/dekriminalisering. Det virker som om mange enda ikke vil innse at kriminalisering er det ultimate frislipp, på tross av den enorme svarte økonomien som omsetter ulovlige rusmidler for milliarder. Det er global tilgjengelighet $\mathrm{i}$ bygd og by av alle mulige mer eller mindre helseskadelige rusmidler uten restriksjoner for barn og ungdom. Udeklarerte produkter øker skadeomfanget av omtrent alle typer rusbruk, og fører til økt risiko sammenlignet med bruk av rusmidler med kjent styrke og renhet. Analyser av kloakken tyder på at forbudspolitikken ikke avskrekker (6), på tross av det mange vil klassifisere som umenneskelige høye strafferammer. Oftest rammer lovverket fattige og problematiske brukere, som med fordel kunne blitt møtt med økonomisk, medisinsk og psykiatrisk hjelp fremfor moralistiske sanksjoner som bøter og fengselsstraff.

\section{Brage Wollnick}

bwollnick@hotmail.com

Brage Wollnick (f. 1988).

Ingen oppgitte interessekonflikter.

Litteratur

1. Bramness JG. Cannabis som medisin. Tidsskr Nor Lægeforen 2015; 135: 252-3. 2. Nutt DJ, King LA, Phillips LD; Independent Scientific Committee on Drugs. Drug harms in the UK: a multicriteria decision analysis. Lancet 2010; 376: 1558-65.

3. Abrams DI, Couey P. Shade SB et al. Cannabinoid-opioid interaction in chronic pain. Clin Pharmacol Ther 2011; 90: 844-51.

4. DeRosse P, Kaplan A, Burdick KE et al. Cannabis use disorders in schizophrenia: effects on cognition and symptoms. Schizophr Res 2010: 120: 95-100.

5. The Drug Policy Alliance. 10 facts about marijuana. www.drugpolicy.org/ drug-facts/10-facts-about-marijuana (23.2.2015)

6. Thomas KV, Bijlsma L, Castiglioni $\mathrm{S}$ et al. Comparing illicit drug use in 19 European cities through sewage analysis. Sci Total Environ 2012; 432: 432-9.

\section{Re: Cannabis som medisin}

Takk til Bramnes for en informativ og fordomsfattig kronikk (1)! Det er på tide at det endocannabinoide nervesystemet blir aktualisert her til lands, og at cannabisplantens rolle og potensial som legemiddel blir belyst fra et farmakologisk perspektiv. Videre følger i all ydmykhet, et par tekniske korreksjoner:

Bramnes sier at det er urealistisk at cannabis vil bli tilgjengelig i norske og europeiske apotek, blant annet på grunn av manglende farmasøytisk kvalitet - dette på tross av at cannabismedisinen Sativex formidles via apotek i 17 europeiske land (2). I Nederland produseres fire varianter medisinsk cannabis (tørkede cannabisblomster med forskjellig THC/CBD-nivå) i regi av det statlige organet Het Bureau voor Medicinale Cannabis (BMC) (3). BMC fraråder imidlertid røyking av blomstene, og anbefaler en langt mindre skadelig inntaksmetode kalt «fordampning», hvor virkestoffene frigjøres ved lavere temperaturer uten den skadelige røyken som oppstår når plantematerialet brennes. De driver også egen forskning for å avklare skadepotensialet for denne metoden, sammenlignet med røyking.

Den uformelle praksisen foretrukket av mange medisinske brukere (legalt eller illegalt) er ikke å røyke, men å spise cannabisen. Virkestoffene i cannabisplanten er fettløselige og kan ekstraheres ved å legge blomstene i oppvarmet matolje/smør. Videre brukes fettekstraktet til matlaging, eller inntas direkte som man ville gjort med tran. Denne metoden eliminerer skadene knyttet til røyking (KOLS, kreft). Doseringen vil fortsatt være vanskelig å fastslå så lenge produktet ikke er testet og kommer uten varedeklarasjon. Nederland har langt på vei klart å løse dette problemet ved å produsere og teste sin egen cannabis. 
Til slutt må det nevnes at Sativex ikke er en nesespray, men en munnspray.

\section{Ruben Solvang}

post@rubensolvang.com

Ruben Solvang (f. 1985) er selvstendig næringsdrivende.

Ingen oppgitte interessekonflikter.

Litteratur

1. Bramness JG. Cannabis som medisin. Tidsskr Nor Legeforen 2015; 135: 252-3.

2. GW pharmaceuticals www.gwpharm.com/GW\%20Pharmaceuticals $\% 20$ plc $\% 20$ Announces\%20Sativex\%20Regulatory\%20Approval\%20in\%20Switzerland.aspx (19.2.2015).

3. Het Bureau voor Medicinale Cannabis www.cannabisbureau.nl/en/ MedicinalCannabis/ (19.2.2015)

\section{Re: Cannabis som medisin}

Legaliseringskampanjen, styrt av sterke økonomiske krefter som tobakksindustrien, bruker varierende argumenter for legalisering av cannabis. Medisinsk nytte har vært én av disse. Som Jørgen Bramness skriver i sin kronikk i Tidsskriftet nr. 3/2015, er dette et retorisk knep (1).

Heroin er et utmerket smertestillende middel. Men det er fortsatt stort sett enighet om at det også er et illegalt rusmiddel med en rekke bivirkninger og komplikasjoner. Cannabinoidene kan inndeles i tre grupper: Endocannabinoider (Anandamid, AG, Nolan eter), plantecannabinoider (marihuana, hasj og hasjolje) og syntetiske cannabinoider med fem undergrupper.

Den medisinske dokumentasjonen for medisinsk nytte er av sterkt varierende kvalitet, fra rene kasuistikker til kontrollerte studier. Best er dokumentasjonen på glaukom, kvalme, appetittstimulering, spastisitet og smerte, i følge en fersk oppsummering (2). Andre tilgjengelig legale medikamenter kan ofte gi bedre effekt.

Det som er problematisk i medisinsk sammenheng er at man ikke kjenner tetrahydrocannabinol/cannabidiol (THC/CBD) innholdet i plantecannabinoidene som røykes. Fra beslag vet man at THCinnholdet øker år for år, mens det beskyttende antipsykotiske CBDinnholdet synker. En joint i dag kan være opptil ti ganger sterkere enn på 70-tallet; fra 1995 til 2012 en firedobling fra 3\% til 12\% (3). En kunne kanskje tro at sterkere marihuana, som skunk, ville føre til nedregulering av bruk, men rapporter fra misbrukermiljø viser at så ikke er tilfelle (4). Marihuana og hasj, som medisinsk preparat, tilfredsstiller ikke de farmasøytiske kravene man må stille til et legemiddel. Da kan det være mer aktuelt med rene farmasøytiske preparater.

Vi som arbeider med cannabisavhengige ungdommer og som ser baksiden av medaljen, kan også se at pasienter med enkelte sykdomstilstander kan profittere på behandling med cannabinoider, der man kjenner innholdet. Sativex-spray er siden 2012 godkjent indikasjon for spastisitet hos MS-pasienter, og Marinol-kapsler har vært brukt i begrenset omfang (på registreringsfritak) som antiemetika hos pasienter under cytostatikabehandling.

Dette gir ingen argumenter for legalisering. Rapporter fra USA viser at stater som har innført hasj og marihuana på resept fra leger, har vært lite nøye med indikasjonen (5). Kun $2 \%$ av forskrivningen har vært for lidelser der cannabinoidene har dokumentert effekt. Leder av National Institute of Drug Abuse i USA, Nora Volkow, er bekymret for praksisen (2): «This practice raises particular concerns with regard to long-term use by vulnerable population». Vi ønsker heller ikke en slik utvikling.

\section{Øistein Kristensen}

oistein.kristensen@sshf.no

Øistein Kristensen (f. 1945) er overlege ved Avdeling for rus og avhengighetsbehandling Sørlandet Sykehus HF, Kristiansand.

Ingen oppgitte interessekonflikter.
Litteratur

1. Bramness JG. Cannabis som medisin. Tidsskr Nor Legeforen 2015; 135: 252-3

2. Volkow ND, Baler RD, Compton WM et al. Adverse health effects of marijuana use. N Engl J Med 2014: 370: 2219-27.

3. ElSohly MA. Potency monitoring program quarterly report no 123-reporting period 09/16/2013-12/15/2013. Oxford: University of Missisippi; National Center for Natural Products Research 2014

4. Freeman TP, Morgan CJ, Hindocha C et al. Just say 'know': how do cannabinoid concentrations influence users' estimates of cannabis potency and the amount they roll in joints? Addiction 2014; 109: 1686-94.

5. Sabet K. The marijuana landscape; 21 th ECAD Mayors conference, Stockholm, May $19-20 ; 2014$

Lungekreftscreening for asbesteksponerte er blitt debattert i kommentarfeltet under artikkelen «Arbeidsbetinget lungekreft i Sør-Trøndelag» i Tidsskriftet nr. 20/2014.

\section{Re: Arbeidsbetinget lungekreft i Sør-Trøndelag}

Forfatterne har misforstått hovedbudskapet i Helsinki-kriteriene (1) når det gjelder anbefaling av CT som verktøy ved helseundersøkelser av asbestarbeidere.

Vainio skriver følgende i sin lederartikkel (2): «The current Helsinki criteria update recommends that individuals with a history of past exposure to asbestos, who meet the absolute lung cancer risk criteria set by randomized trials and existing lung cancer screening guidelines, should be offered screening with low-dose CT».

De omtalte randomiserte studiene gjelder gjennomførte studier (i hovedsak de amerikanske undersøkelsene som viser økt overlevelse hos røkere undersøkt med CT), som brukes som grunnlag for å sette inklusjonskriterier for helseundersøkelser. Dette er gjennomgående for etablerte programmer for helseundersøkelser av asbestarbeidere. Helsinki-kriteriene omtaler forskning, men det $i$ betydning av følgeforskning og kvalitetssikring av programmer for helseundersøkelser av asbestarbeidere. Etablering av et slikt program i Norge med nødvendige ressurser er knyttet til faglige myndigheters ansvar i henhold til lov og forskrift.

\section{Vemund Digernes}

vemu-d@online.no

Vemund Digernes (f. 1945) er dr.med., pensjonist og tidligere fagsjef ved Norsk Industri.

Ingen oppgitte interessekonflikter.

Litteratur

1. Wolff H, Vehmas T, Oksa P et al. Asbestos, asbestosis, and cancer, the Helsink criteria for diagnosis and attribution 2014: recommendations. Scand J Work Environ Health 2015; 41: 5-15.

2. Vainio H. Epidemics of asbestos-related diseases - something old, something new. Scand J Work Environ Health 2015; 41: 1-4.

\section{Re: Amfetaminutløst psykose eller schizofreni?}

Kronikken til Rognli og medarbeidere i Tidsskriftet nr. 3/2015 påpeker en avgjørende utfordring $i$ diagnostisering og behandling av pasienter med samtidig alvorlig rus- og psykisk lidelse (1). Mens ruslidelsen vil kunne avsløres forholdsvis lett med en biologisk prøve (blod, urin eller spytt), er vi langt fra et biologisk korrelat som bekrefter psykiske lidelser, som for eksempel schizofreni. Her er samtalen og fortolkingen av denne fortsatt sentral. Vi anerkjenner derfor at en travel hverdag på en hvilken som helst sykehusavdeling vil kunne friste til å fortolke radikalt; nemlig at inntak av amfetamin er tilstrekkelig for å vurdere pasientens samtidige psykotiske opplevelse som rusutløst. Det er derimot ikke tatt hensyn til at positive prøver ikke alene kan diagnostisere alvorlige psykiske lidelser, uten at de for- 